\title{
Poesia e polícia: redes de comunicação na Paris do século XVIII.
}

\author{
Robert Darnton \\ Tradução Rubens Figueiredo \\ São Paulo: Companhia das Letras, 2014
}

\begin{abstract}
O historiador norte-americano Robert Darnton, amplamente conhecido no ambiente acadêmico brasileiro, é um dos grandes pesquisadores da história intelectual do século XVIII - um tema que geralmente abrigamos sob o guarda-chuva conceitual do lluminismo.

Sua familiaridade com a antropologia cultural, sobretudo por conta da sua proximidade com os estudos de Clifford Geertz, bem como o cuidado obsessivo que dedica à pesquisa documental nos arquivos franceses fazem dos seus trabalhos verdadeiras incursões em universos desconhecidos, causando, como ocorre com as boas descrições etnográficas, estranhamento em relação às realidades que julgamos conhecer.
\end{abstract}

Neste Poesia e polícia não é diferente. Darnton, que dirige a biblioteca da Universidade de Harvard, volta aos arquivos parisienses e consegue reconstruir uma intrincada rede que ligava o submundo francês ao ambiente da corte de Luís XV no final da década de 1740. Uma denúncia anônima de um espião em 1749 leva a estrutura policial da monarquia à perseguição e à prisão de catorze indivíduos, entre estudantes universitários, jovens clérigos e pequenos funcionários da estrutura da justiça, envolvidos na produção e na difusão clandestina de poesias e canções que satirizavam medidas do governo e ofendiam o rei e sua amante, Jeanne-Antoinette Poisson, a marquesa de Pompadour.

Com idades que variavam entre dezesseis e trinta e um anos, os envolvidos no "Caso dos Catorze", como ficou conhecido, eram provenientes das camadas médias parisienses. Pessoas que não faziam parte da elite política francesa mas eram bem educadas e em dia com as decisões da monarquia referentes à política externa e seus desdobramentos internos. Clérigos jansenistas que não se dobravam à vontade do rei, estudantes irreverentes (de Direito, majoritariamente), professores conectados às discussões científicas, funcionários desobedientes - pessoas capazes de versificar sátiras em francês e em latim e ouvir o burburinho das ruas, combinando tudo isso com os mexericos da corte. O personagem mais intrigante desta rede, sobre quem Darnton dedica, infelizmente, pouca atenção, era o professor de filosofia chamado Pierre Sigorne. O professor se negou a falar, não entregou um único nome e a investigação emperrou nele. Entusiasta dos princípios newtonianos, Sigorne era o centro de um grupo do qual faziam parte, entre outros, Anne Robert Jacques Turgot (futuro ministro das Finanças de Luís XVI) e Denis Diderot (futuro editor da Enciclopédia).

Os versos apreendidos naquela ocasião atacavam o centro do poder real e eram recitados, copiados, emendados, recriados, musicados, memorizados e discutidos por pessoas que se preocupavam com seus aspectos políticos e poéticos. Retornando às sátiras cantadas em 1747, Darnton consegue 
observar uma sutil mudança no corriqueiro hábito de maldizer autoridades através do riso, identificando fatos da vida política que acabaram constituindo interseções entre a velha política da corte e uma crescente conexão entre indivíduos do mundo da rua interessados em falar sobre uma esfera de decisões da qual estavam alijados. Como isto ocorreu?

Darnton, a partir de documentos de arquivo e de memórias produzidas ao longo do século XVIII, reconstitui os eventos que levaram à demissão do conde de Maurepas, secretário de Estado, em abril de 1749. O astuto nobre foi responsável por um vazamento de informação sobre um jantar oferecido pelo rei e por sua amante, informação esta que chegou às ruas de Paris por meio de uma sátira - Pompadour havia oferecido aos poucos convivas, entre eles o próprio Maurepas, flores brancas (fleurs blanches), o que se tornou, nos cafés e becos parisienses, "fluxos brancos" (flueurs blanches), referência a doença venérea. A polícia foi acionada e passou a fazer as prisões, levando à Bastilha pessoas acusadas de pertencer a uma rede que recitava e distribuía poemas satíricos, em cujos versos também apareciam medidas impopulares de Luís XV, como a ordem de prisão contra um príncipe inglês exilado em Paris, um acordo de paz vexatório e o lançamento de um novo imposto. Nos poemas e nos cantos que circulavam na capital francesa, reproduzidos na íntegra na obra, as fofocas cortesãs sobre a vida íntima dos governantes estavam associadas à carência de virtude nas decisões reais recentes. Mais do que isso: aparentemente, o rei e seus auxiliares mais próximos passaram a se importar de uma maneira até então não vista sobre a forma como estas conexões estavam sendo feitas em lugares públicos, sem o controle das autoridades.

A estrutura repressiva francesa, a partir daí, infiltrou espiões, pagou informantes, prendeu e interrogou suspeitos cujos depoimentos oferecem ao historiador de hoje material para entrar em contato com este universo nem sempre muito distante do nosso: a tentativa, nunca suave, de estabelecer um ambiente público de discussão.

Ficou de fora do trabalho uma discussão mais detida sobre o papel da sátira nas sociedades da Época Moderna. Embora se preocupe em observar aspectos tradicionais da cultura popular no maldizer público de autoridades, Darnton não atenta para aspectos intrínsecos à atitude satírica que poderiam oferecer outra camada de significados para o Caso dos Catorze, bem como para a maledicência social ao longo do Antigo Regime. Gilbert Highet, em estudo clássico sobre o tema, demonstra a ambivalência da atitude satírica, que pode ser cáustica em relação aos indivíduos atacados, mas tende a reforçar uma determinada ordem social. ${ }^{1}$ As sátiras que fazem parte do caso estudado por Darnton são paródias, versificações compostas sobre estruturas monológicas previamente conhecidas pela audiência, o que reforça ainda mais o impacto de valores previamente defendidos por um público amplo - por exemplo, a gravidade cristã da vida sexual do rei, que estaria refletida, de algum modo, em suas virtudes políticas. Darnton também deixa de fora questões específicas relativas às estruturas poéticas ou narrativas utilizadas pelos letrados para produzir as sátiras, abrindo mão, portanto, de ferramentas oriundas da análise poética ou da crítica literária, de modo algum desprezíveis para a consideração de poemas como fontes para o historiador. Mais preocupado em reconstruir conexões entre grupos e acontecimentos políticos e culturais, pouco avança no escrutínio de um complexo cultural que também era informado por uma dimensão discursiva habitada e manipulada por indivíduos letrados.

\footnotetext{
${ }^{1}$ HIGHET, Gilbert. The anatomy of satire. Princeton: Princeton University Press, 1962. 
Autor de obra clássica sobre um ícone do lluminismo² - a Enciclopédia de Diderot e D’Alembert -, Darnton há muito também se dedica à "subliteratura" que roía, nos becos, nos cafés e nos salões menos nobres, as imagens até então impolutas dos velhos poderes. Um exemplo recente é o seu $O$ diabo na água benta, saído no Brasil em $2012^{3}$, no qual acompanha a corrida de gato e rato entre a polícia francesa e os autores de libelos que se espalhavam dos dois lados do Canal da Mancha no século XVIII.

O historiador se dedica, em Poesia e polícia, às relações entre personagens anônimos que levavam e traziam palavras proibidas, mostrando que, além dos textos, as relações dos indivíduos e dos grupos com o conhecimento e com os escritos acabaram por engendrar um ambiente novo, base de um mundo que nos deveria ser familiar.

De linguagem acessível, a obra estabelece brevemente os problemas conceituais referentes à esfera pública, fazendo alusão aos textos basilares de Foucault e Habermas - o primeiro, mais preocupado com uma abordagem filosófica, segundo a qual uma coisa só existe quando é nomeada (portanto, a "opinião pública" não poderia existir antes de ser assim nomeada, no final do século XVIII), enquanto o segundo está mais interessado em uma abordagem sociológica (isto é, a coisa existe desde que seja percebida como tal pelo estudioso, no presente). Sem se satisfazer completamente com nenhum dos dois teóricos, Darnton lança mão das ferramentas vindas da antropologia - a imersão em uma cultura estranha e a tentativa de compreendê-la a partir dos seus próprios termos - para tentar ouvir as vozes de um mundo distante do século XXI. Assim, observa, por um lado, como Condorcet, um matemático, historiador e filósofo iluminista cooptado pelo Estado francês nos estertores do Antigo Regime, acreditava no projeto ilustrado de estabelecimento gradual da razão a partir da discussão pública, impressa, serena, que levaria a sociedade ao progresso; e, por outro, como Luis-Sébastien Mercier, dramaturgo, jornalista, escritor mediano, descreveu "o público" como um poder que vinha da rua, irresistível e contraditório, mas capaz de destronar a tirania. Condorcet foi decapitado durante o Terror; Mercier, que desprezava o heliocentrismo e a física newtoniana, foi nomeado professor de história pelo governo revolucionário.

Embora curto, o livro de Robert Darnton é uma esclarecedora incursão em um momento-chave no complicado processo de estabelecimento de um lugar de discussão política alheio à vontade do Estado. $O$ resultado é belíssimo, sobretudo para nós que, autocentrados, acreditamos que inventamos, por força da internet, a sociedade da informação. A cultura não oficial, fragmentada e transmitida habilmente entre jovens indivíduos descontentes fez estragos na vida de quem morava em palácios nos século XVIII.

Rodrigo Elias

Revista de História da Biblioteca Nacional rodrigoelias2@gmail.com

\footnotetext{
2 DARNTON. Robert. O Iluminismo como negócio: história da publicação da "Enciclopédia", 1775-1800. Tradução Laura Teixeira Motta e Marcia Lucia Machado (textos franceses). São Paulo: Companhia das Letras, 1996.

${ }^{3}$ DARNTON. Robert. O diabo na água benta Ou a arte da calúnia e da difamação de Luís XIV a Napoleão. Tradução Carlos Afonso Malferrari. São Paulo: Companhia das Letras, 2012.
} 